\title{
Influence of Different Thawing Methods on Physico-chemical and Microbiological Characteristics of Broiler Chicken Meat
}

\author{
R. Rajkumar, A. Irshad*, and C. Pandiyan \\ Department of Livestock Products Technology (Meat Science), Veterinary College and \\ Research Institute, Namakkal, TANUVAS, Tamil Nadu, India \\ *Corresponding author
}

\section{A B S T R A C T}

\begin{tabular}{|l|}
\hline Key w or d s \\
$\begin{array}{l}\text { Frozen broiler meat, } \\
\text { Thawing methods, } \\
\text { Microbiological } \\
\text { characteristics }\end{array}$ \\
\hline Article Info \\
$\begin{array}{l}\text { Accepted: } \\
10 \text { October } 2020 \\
\text { Available Online: } \\
10 \text { November } 2020\end{array}$ \\
\hline
\end{tabular}

A good thawing of broiler meat is one that minimizes process time and microbial growth risk. Hence, the present study was carried out to investigate the influence of physicochemical and microbiological characteristics of broiler chicken meat and leg samples by different thawing methods. The thawing methods like room temperature, running tap water, refrigerator and microwave oven thawing were selected and studied. The various thawing methods didn't influence the drip loss per cent, $\mathrm{pH}$ value of broiler breast and leg meat samples. The water holding capacity has been slightly increased corresponding with earlier research reports. Further, the water activity of broiler breast was little higher as compared to leg meat in microwave oven thawing than the others methods. The physical properties of toughness and firmness of broiler breast and leg meat has been meagerly influenced with respect to thawing methods. The total viable count of microwave oven thawed meat samples had less count than the other methods. E. coli and Salmonella species were not noticed in the broiler meat samples during the entire period of the experiment.

\section{Introduction}

Low temperature storage is the most common method used for meat and meat products preservation. However, some quality changes will still take place during freezing, frozen storage and thawing, especially texture, flavour and colour due to osmotic removal of water, oxidation of protein and fat, myosin denaturation and mechanical damage (Benjakul et al., 2003). Scientifically meat refrigeration process has been done by reducing the temperature of the meat to a value below which the rate of bacterial growth is either severely slowed (chilling) or stopped (freezing). Freezer storage is an excellent method of meat preservation than chilling process. The length of time meat samples are held at frozen storage also determines product quality. Freezing reduces enzyme activity in meat and stops the growth of bacteria and molds and therefore the quality of the meat is retained longer, as compared to freezing cooked meat or poultry. When frozen meat is thawed, much of the original moisture found in the meat is lost as purge (juices that flow from the meat). A good thawing regime is one that minimizes process time, microbial growth risks, drip loss, and other quality losses. The main 
objective of this study is to analyze the effect of different thawing method on the physicochemical and microbiological characteristics broiler chicken meat. Hence the experiment designed for thawing of broiler chicken meat at different methods such as room temperature (as control), running tap water (at 28 degree Celsius) refrigerator condition (at 4 ${ }^{\circ} \mathrm{C}$ ) and microwave oven thawing.

\section{Materials and Methods}

The study materials of forty eight pairs of musculus pectoralis and leg portion were sourced from 35-day old ROSS 308 broiler chickens held together in one production cycle on liter with unlimited access to standard feed mixtures dedicated for broiler chickens. Slaughtering and dissection of the chickens was undertaken at Department of livestock products technology (meat science), Veterinary College and Research Institute, Namakkal, Tamil Nadu, according to industry standards set for poultry slaughter houses. The birds were mechanically slaughtered after antemortem examination and subsequently allowed for blood-letting, plucked and mechanically gutted. The carcasses were chilled in water $\left(2^{\circ} \mathrm{C}\right)$ and the chilled carcasses were mechanically dismembered and the skinless breast meat and leg piece were manually cut out. The study materials were packed in LDPE sachets and stored under $-18^{\circ} \mathrm{C}$ for a week. On the day of experiment, samples were transported to the laboratory by using insulated box made of stainless steel. The experiment was conducted at Department of livestock products technology (meat science), Veterinary College and Research Institute, Namakkal, Tamil Nadu state, India.

The packed frozen broiler meat samples were unsealed and the meat packs were thawed viz.

(a) Room temperature $\left(30 \pm 2^{\circ} \mathrm{C}\right)$, (b)

Running tap water $\left(28 \pm 1^{\circ} \mathrm{C}\right), \quad$ (c)
Refrigeration $\left(4 \pm 1^{\circ} \mathrm{C}\right)$ and (d) Microwave oven (2450 MHZ) respectively. The time taken for thawing at room temperature was 180 minutes; running water was 60 minutes; at refrigeration temperature was 14 hours and in microwave oven was 10 minutes for the samples.

Weight of the experimental meat samples were recorded before and after thawing. Drip loss of the chicken breast and leg meat (expressed as per cent moisture lost) was determined as per the method suggested by Benli (2016). The estimation of $\mathrm{pH}$ of meat sample was measured by using digital $\mathrm{pH}$ meter (Model 361, Systronics, India). About $5 \mathrm{~g}$ of meat was homogenized in a tissue homogenizer with $45 \mathrm{ml}$ of distilled water for about one minute. The $\mathrm{pH}$ was recorded by immersing the combined glass electrode of digital $\mathrm{pH}$ meter in the homogenate. Water holding capacity of meat sample (as percent water retained by the meat sample) was analyzed by filter paper press method as suggested by Hamm (1960) with slight modification. $500 \mathrm{mg}$ of meat was pressed between two filter papers by applying $2.8 \mathrm{~kg}$ weight for 5 mins. Weight of meat flake and filter paper after pressing was recorded.

The firmness and toughness of breast and leg meat was analyzed by using the food texture analyzer (model: TA-XT plus, Stable Microsystems), connected to a computer programmed with the texture analysis software. Thirty-six measurements for each meat samples were recorded. The term firmness is the maximum peak force $(F)$ during the first compression cycle (first bite) and the unit is Newton.

The total viable count (TVC), E. coli and Salmonella count of broiler breast and leg meat samples were carried out as per the procedure followed by Bhandari et al., (2013). 
A total of twelve replications were made to find out the suitable thawing procedure for broiler meat. Statistical analyses were performed using SPSS software (SPSS $15.0 \mathrm{~K}$ for Windows, Chicago, IL), and all data were expressed as means \pm standard error of the mean (SEM) values. Data were submitted to one-way analysis of variance. Significant differences among means of the nine replicates were compared by Tukey's test at $\mathrm{p}<0.05$.

\section{Results and Discussion}

\section{Drip loss (\%)}

The results of the weight $(\mathrm{g})$ of investigated broiler meat samples before thawing had a mean value of $1.44,1.40,1.45$ and 1.37 for the treatments Control, T1, T2 and T3 respectively and noticed no significant difference among them. Similarly, the weight (g) of meat samples after thawing had a mean value of $1.42,1.37,1.43$ and 1.36 for the Control and treatments and had no significant difference among them. The drip loss (per cent) of the control and experimental groups (T1 to T3) were $1.61,2.13,1.00$ and 1.60 respectively and looked a similar trend as that of before and after thawing weight.

Benli, (2016) studied the drip loss per cent of chicken breast obtained from a retail market and placed in a freezer at $-20^{\circ} \mathrm{C}$ for 72 hours for three days. The chicken breast samples after defrosting using home based thawing practices such as i) thawing in a refrigerator $\left(+4^{\circ} \mathrm{C}, 24\right.$ hours $)$; ii) thawing on a counter at room temperature $\left(22^{\circ} \mathrm{C}, 6\right.$ hours $)$; iii) thawing in warm water $\left(37^{\circ} \mathrm{C}, 40\right.$ minutes); iv) thawing in a microwave (180 W, 10 to 13 minutes); and $\mathrm{v}$ ) thawing under tap water $\left(20^{\circ} \mathrm{C}, 1\right.$ hour $)$ and reported $0.62,1.47,0.93$, 3.47 and 1.14 respectively. Woelfel et al., (2002) and Van Laack et al., (2000) reported a mean drip loss values laid between $0.42 \%$ and $3.32 \%$ for broiler meat in the commercial processing plants. The various thawing methods viz., room temperature, tap water, refrigerator and microwave has little variation in the drip loss as compared to each other but the variation is not statistically significant. In the present investigation, the broiler meat samples has been purchased from commercial local retail sale outlets the drip loss percentage were in accordance with the findings of Benli, (2016), Woelfel et al., (2002) and Van Laack et al., (2000) respectively. In general, poultry meat is far less prone to drip as suggested by Emad et al., (2014). The drip loss of muscle can lead to less acceptability, due to the loss of tasteful constituents, e.g. some amino acids or nucleotides.

\section{pH Value}

In the present study, the $\mathrm{pH}$ of breast meat sample had a significant difference $(\mathrm{P}<0.01)$ between control and treatments and the room temperature thawed breast meat has low $\mathrm{pH}$ value as compared to treatments (Table 1). Tap water, refrigerator and microwave thawing has no effect in the $\mathrm{pH}$ value and are at par with one another. Saelin et al., (2017) studied the $\mathrm{pH}$ of non-marinated broiler breast meat stored at $4{ }^{\circ} \mathrm{C}$ on day 0 was 6.08 and on day 10 was 6.27. Anna et al., (2018) studied the $\mathrm{pH}$ of stored frozen broiler chicken breast meat up to one month and thawed using atmospheric air, water, and microwave oven and reported a $\mathrm{pH}$ value of 5.96, 6.01 and 5.91 respectively. Effect of thawing temperature viz., $2^{\circ} \mathrm{C}, 18^{\circ} \mathrm{C}$ and $0^{\circ} \mathrm{C}$ on $\mathrm{pH}$ of pre-rigor frozen chicken breast muscles were $5.83,5.77$ and 5.79 respectively. The ultimate $\mathrm{pH}$ of $18{ }^{\circ} \mathrm{C}$ thawed muscle was lower than that of $0^{\circ} \mathrm{C}$ thawed and $2{ }^{\circ} \mathrm{C}$ chilled muscles (Yu et al., 2005). The present results pertaining to the breast meat are in accordance with the findings of Saelin et al., (2017), Anna et al., (2018) and Yu et al., 
(2005) respectively. Benli, (2016) evaluated the $\mathrm{pH}$ value of chicken breast obtained from a retail market and placed in a freezer at $20^{\circ} \mathrm{C}$ for 72 hours for three days. The chicken breast samples after defrosting using home based thawing practices such as i) thawing in a refrigerator $\left(+4^{\circ} \mathrm{C}, 24\right.$ hours $)$; ii) thawing on a counter at room temperature $\left(22^{\circ} \mathrm{C}, 6\right.$ hours); iii) thawing in warm water $\left(37^{\circ} \mathrm{C}, 40\right.$ minutes); iv) thawing in a microwave $(180 \mathrm{~W}$, 10 to 13 minutes); and v) thawing under tap water $\left(20^{\circ} \mathrm{C}, 1\right.$ hour $)$ had a $\mathrm{pH}$ value of 6.10 , $6.07,6.14,6.20$ and 6.18 respectively. The $\mathrm{pH}$ value of leg meat of had a significant difference $(\mathrm{P}<0.01)$ between control and treatments. Mostly all the thawing methods had a similar trend in the $\mathrm{pH}$ value of leg meat but there is a marked difference has been noticed statistically in the tap water and microwave oven thawing methods over the refrigerator thawing. Yu et al., (2005) studied the effect of thawing temperature on pre-rigor frozen chicken leg muscles stored viz., $2^{\circ} \mathrm{C}$, $18^{\circ} \mathrm{C}$ and $0^{\circ} \mathrm{C}$ had a $\mathrm{pH}$ value of $6.15,6.10$ and 6.12 respectively. The $\mathrm{pH}$ value of broiler leg meat in the current investigation is at par with reported $\mathrm{pH}$ values of $\mathrm{Yu}$ et al., (2005).

\section{Water Holding Capacity (WHC)}

The major risk to the quality of frozen meat is the reduction of water holding capacity (WHC), which is manifested as loss of exudate upon thawing. The water holding capacity $(\%)$ of breast meat samples for the control and treatments were 74.28, 72.09, 70.34 and 70.79 respectively and showed no significant difference among them. The water holding capacity (\%) of leg meat samples for the control and treatments were $77.15,70.20$, 66.68 and 71.70 respectively and exhibited a significant difference $(\mathrm{P}<0.01)$ among them. Room temperature thawed broiler leg meat has higher amount of WHC than the other methods. Netsai et al., (2015) reported that the WHC of the chicken breast thawed by water immersion thawing (control) had 63.36 per cent and for the ohmic thawing treatments (at different electrical field strengths from 2.5 to $10 \mathrm{~V} / \mathrm{cm}$ and $\mathrm{NaCl}$ concentrations from 0.00 to $0.14 \% \mathrm{w} / \mathrm{w})$, the $\mathrm{WHC}$ was in the range of 62.76 to $65.42 \%$ respectively and showed no significant difference among them. Ali et al., (2016) found that the broiler breast meat samples kept at $-20^{\circ} \mathrm{C}$ and subjected to zero (fresh) freeze-thawing had around 52 per cent of WHC. The present results pertaining to WHC of broiler breast and leg meat had a higher water holding capacity as compared to the values of Netsai et al., (2015) and Ali et $a l$., (2016). The method of analysis of water holding capacity of meat samples might also be a reason for the variation in the present study. The higher water-holding capacity of roe deer meat samples stored at $-26^{\circ} \mathrm{C}$ for 10 months could be attributed to the fact that they had slightly lower water content (greater thawing drip loss) and a higher content of proteins that could bind water (Tomasz et al., 2018). The present results of WHC of broiler breast and leg meat samples could be related with the opinion of Tomasz et al., (2018).

\section{Water activity (aw)}

The water activity of breast meat samples had a significant difference $(\mathrm{P}<0.05)$ between control (0.95) and treatments T1 (0.95), T2 (0.95) and T3 (0.96) respectively. Microwave oven thawing of broiler breast meat has higher water activity than the other methods of thawing. The water activity of leg meat samples had a significant difference $(\mathrm{P}<$ $0.01)$ between control (0.94) and treatments T1 (0.95), T2 (0.95) and T3 (0.95) respectively. Oliveira et al., (2015) studied the water activity of frozen (fast freezing to $36{ }^{\circ} \mathrm{C}$ in 2 hours) chicken half breast samples and stored under freezing temperatures (-18 $\left.{ }^{\circ} \mathrm{C}\right)$. The samples were thawed by using methods like refrigerator, microwave oven, electric oven, immersion in water and room 
temperature and the values were $0.991,0.993$, $0.993,0.993$ and 0.992 respectively. Elgadir (2017) reported that broiler chicken breast muscles (Fed with standard mixture) had aw value of 0.96 and increased to 0.99 at the end of the storage period of one week at $4^{\circ} \mathrm{C}$. In the present study, the microwave oven thawing of broiler breast meat has higher water activity than the other methods of thawing. In case of leg meat, room temperature thawing had little lower water activity as compared to other thawing methods. It is evident that the water activity of broiler breast and leg meat was not affected by thawing methods and the findings are at par with those of Oliveira et al., (2015) and Elgadir (2017).

Table.1 Physico-chemical and microbiological properties of various thawing process on the quality of frozen broiler meat samples

\begin{tabular}{|c|c|c|c|c|}
\hline $\begin{array}{l}\text { Parameters* } \\
(\text { Mean } \pm \text { SE) }\end{array}$ & $\begin{array}{l}\text { TC }(\text { Control }) \\
\text { Room Temp }\end{array}$ & $\begin{array}{c}\text { T1 } \\
\text { Tap Water }\end{array}$ & $\begin{array}{c}\mathrm{T} 2 \\
\text { Refrigerator }\end{array}$ & $\begin{array}{c}\text { T3 } \\
\text { Microwave }\end{array}$ \\
\hline Weight of broiler meat before thawing $(\mathrm{g}){ }^{\mathrm{NS}}$ & $1.44 \pm 0.03$ & $1.40 \pm 0.02$ & $1.45 \pm 0.01$ & $1.37 \pm 0.03$ \\
\hline Weight of broiler meat after thawing (g) ${ }^{\mathrm{NS}}$ & $1.42 \pm 0.02$ & $1.37 \pm 0.02$ & $1.43 \pm 0.01$ & $1.36 \pm 0.03$ \\
\hline Drip loss $(\%)^{\mathrm{NS}}$ & $1.61 \pm 0.386$ & $2.13 \pm 0.398$ & $1.00 \pm 0.092$ & $1.60 \pm 0.129$ \\
\hline $\begin{array}{l}\mathrm{pH} \text { of breast meat } \\
(\mathrm{P}<0.01)\end{array}$ & $5.70^{\mathrm{ab}} \pm 0.04$ & $6.22^{\mathrm{a}} \pm 0.09$ & $5.99^{\mathrm{a}} \pm 0.12$ & $6.13^{\mathrm{a}} \pm 0.12$ \\
\hline $\begin{array}{l}\mathrm{pH} \text { of leg meat } \\
(\mathrm{P}<0.01)\end{array}$ & $6.46^{\mathrm{a}} \pm 0.05$ & $5.99^{\mathrm{ab}} \pm 0.16$ & $6.23^{\mathrm{a}} \pm 0.10$ & $5.94^{\mathrm{ab}} \pm 0.10$ \\
\hline Water holding capacity of breast meat $(\%)^{\mathrm{NS}}$ & $74.28 \pm 1.33$ & $72.09 \pm 2.17$ & $70.34 \pm 1.40$ & $70.79 \pm 0.76$ \\
\hline $\begin{array}{l}\text { Water holding capacity of leg meat }(\%)(\mathrm{P} \\
<0.01)\end{array}$ & $77.15^{\mathrm{a}} \pm 0.82$ & $70.20^{\mathrm{b}} \pm 1.35$ & $66.68^{\mathrm{b}} \pm 1.05$ & $71.70^{\mathrm{b}} \pm 0.52$ \\
\hline Water activity of breast meat $(\mathrm{P}<0.05)$ & $0.95^{\mathrm{b}} \pm 0.004$ & $0.95^{\mathrm{b}} \pm 0.004$ & $0.95^{\mathrm{b}} \pm 0.005$ & $0.96^{\mathrm{a}} \pm 0.004$ \\
\hline Water activity of leg meat $(\mathrm{P}<0.01)$ & $0.94^{\mathrm{ab}} \pm 0.004$ & $0.95^{\mathrm{a}} \pm 0.004$ & $0.95^{\mathrm{a}} \pm 0.002$ & $0.95^{\mathrm{a}} \pm 0.002$ \\
\hline $\begin{array}{l}\text { Firmness of breast meat } \\
(\mathrm{P}<0.01)\end{array}$ & $4.31^{\mathrm{a}} \pm 0.208$ & $3.48^{\mathrm{ab}} \pm 0.124$ & $4.10^{\mathrm{a}} \pm 0.205$ & $3.28^{\mathrm{ab}} \pm 0.186$ \\
\hline Firmness of leg meat NS & $5.80 \pm 0.280$ & $5.86 \pm 0.349$ & $5.92 \pm 0.312$ & $5.75 \pm 0.396$ \\
\hline Toughness of breast meat $(\mathrm{P}<0.01)$ & $28.72^{\mathrm{a}} \pm 1.416$ & $24.99^{\mathrm{a}} \pm 1.675$ & $26.95^{\mathrm{a}} \pm 1.408$ & $22.81^{\mathrm{ab}} \pm 1.402$ \\
\hline Toughness of leg meat $(\mathrm{P}<0.01)$ & $31.31^{\mathrm{ab}} \pm 2.981$ & $35.34^{\mathrm{a}} \pm 1.961$ & $29.63^{\mathrm{ab}} \pm 2.680$ & $40.06^{\mathrm{a}} \pm 3.035$ \\
\hline $\begin{array}{l}\text { TVC of breast meat } \\
(\log 10 \mathrm{cfu} / \mathrm{g})(\mathrm{P}<0.01)\end{array}$ & $2.79^{\mathrm{a}} \pm 0.04$ & $2.68^{\mathrm{a}} \pm 0.04$ & $2.41^{\mathrm{b}} \pm 0.02$ & $2.28^{\mathrm{c}} \pm 0.02$ \\
\hline TVC of leg meat $(\log 10 \mathrm{cfu} / \mathrm{g})(\mathrm{P}<0.01)$ & $2.73^{\mathrm{a}} \pm 0.03$ & $2.65^{\mathrm{a}} \pm 0.03$ & $2.38^{b} \pm 0.02$ & $2.27^{\mathrm{c}} \pm 0.02$ \\
\hline $\begin{array}{l}\text { E.coli and Salmonella count of breast and } \\
\text { leg meat }(\log 10 \mathrm{cfu} / \mathrm{g})\end{array}$ & \multicolumn{4}{|c|}{ Not detected } \\
\hline
\end{tabular}

$*_{\mathrm{n}}=48$

\section{Texture profile analysis}

The average firmness of breast meat samples had a significant difference $(\mathrm{P}<0.01)$ between control (4.31) and treatments $\mathrm{T} 1$ (3.48), T2 (4.10) and T3 (3.28) respectively. When the groups were compared by the breast meats in terms of firmness, the highest value was found to be in the group thawed at room temperature while the lowest value was found to be in the group thawed by microwave oven. Even though all the thawing methods appear similar but tape water and microwave oven thawing had lesser firmness as compared to the other methods of thawing. The average firmness of leg meat samples had no 
significant difference between control (5.80) and treatments $\mathrm{T} 1$ (5.86), T2 (5.92) and T3 (5.75) respectively. It is evident that firmness of leg meat was higher than that of breast meat, might be due to dense myofibrils in the leg meat.

The average toughness of breast meat samples had a significant difference $(\mathrm{P}<0.01)$ between control (28.72) and treatments $\mathrm{T} 1$ (24.99), T2 (26.95) and T3 (22.81) respectively. When the groups were compared by the breast meats in terms of toughness, the highest value was found in control (room temperature) sample. The lowest value was found in T3 (microwave oven) is significantly different from all other thawing methods. When the toughness of the leg meat is considered, the control and treatment samples are found to be significantly different $(\mathrm{P}<$ $0.01)$. Room temperature thawed leg meat was having higher toughness and is similar to refrigeration thawing. Moreover, the microwave oven thawed meat is at par with tap water thawing. Therefore, it could be inferred that the thawing methods affected the physical properties of toughness and firmness of broiler breast and leg meat. Our findings related to texture properties of the breast and leg meat are in closer to the findings of Lin et al.,(2014) and Hasan et al., (2018) respectively. Lin et al., (2014) studied the firmness and toughness properties (TA-XT plus, Stable Microsystems) of Taiwan game hen breast and thigh meat samples reared under cage, floor and free-range system and the samples were stored at $-20 \pm 1^{\circ} \mathrm{C}$ and thawed at $4 \pm 1^{\circ} \mathrm{C}$ for 12 hours. Taiwan game hen breast meat had firmness of 3.14, 3.42 and 4.64 respectively. Further the firmness of thigh meat had 4.49, 4.22 and 5.99 and the toughness of thigh meat had 22.6,13.2 and 35.3 respectively. Breast meat had 6.88, 6.99 and 9.08 respectively. Free-range birds had greater firmness and toughness in both breast and thigh meat, which was associated with higher collagen content in both breast and thigh meat, compared with the other groups. Hasan et al., (2018) analyzed the cooked broiler breast and leg meat samples for firmness and toughness by using TA-XT Plus Texture Analyzer (Stable Micro Systems, England) and found that breast meat had a firmness $(\mathrm{kg})$ of 2.0 and toughness $(\mathrm{kg})$ of 11.09 and subsequently the leg meat had a firmness $(\mathrm{kg})$ of 2.29 and toughness $(\mathrm{kg})$ of 16.56.

\section{Microbiological quality}

The total viable count (log $10 \mathrm{cfu} / \mathrm{g}$ ) of (TVC) of breast meat and leg meat had a significant difference $(\mathrm{P}<0.01)$ among the control and treatments. Both the samples had a higher count in the room temperature and tape water thawing, followed by refrigeration thawing and finally microwave oven thawing. The result of the total viable count of breast and leg meat are far below to the prescribed limit by the FSSAI, (2012). Moreover, the E.coli and salmonella were absent in these samples.

Based on the findings, it was concluded that the thawing methods such as room temperature, tap water, refrigerator and microwave oven has not much influenced the drip loss, $\mathrm{pH}$ value of broiler breast and leg meat samples. The water holding capacity has been slightly increased corresponding with earlier research reports. Further, the water activity of broiler breast was little higher as compared to leg meat in microwave oven thawing than the others methods. The physical properties of toughness and firmness of broiler breast and leg meat has been meagerly influenced with respect to thawing methods. The total viable count of microwave oven thawed meat samples had less count than the other methods and E. coli and salmonella species are not seen in the broiler meat samples. These microbiological standards are within the prescribed limits by the FSSAI, (2012). 


\section{Acknowledgements}

The authors would like to thank the helps of Scientists and staff of Veterinary College and Research Institute (TANUVAS) and Centre of Excellence in Meat Science and Technology in the experiments including pretreatment and slaughter of birds. This work was carried out by the financial support from Tamil Nadu Veterinary and Animal Sciences University.

\section{References}

Akhtar S, Khan M, Faiz F (2013) Effect of thawing on frozen meat quality: A comprehensive review. Pak J Food Sci 23: 198-211.

Ali SI, Rajput NII, Li CI, Zhang WI, Zhou G. (2016) Effect of freeze-thaw cycles on lipid oxidation and myowater in broiler chickens. Brazilian Journal of Poultry Science., 18(1): $35-40$.

AnnaAugustyn'ska-Prejsnar, Małgorzata Ormian, and Zofia Sokołowicz. (2018) Physicochemical and Sensory Properties of Broiler Chicken Breast Meat Stored Frozen and Thawed Using Various Methods. Hindawi Journal of Food Quality.1-9.

Benjakul S, Visessanguan W, Thongkaew C, Tanaka M. (2003). Comparative study on physicochemical changes of muscle proteins from some tropical fish during frozen storage. Food Res. Int. 36: 787795.

Benli H. (2016)Consumer attitudes toward storing and thawing chicken and effects of the common thawing practices on some quality characteristics of frozen chicken. Asian Australas. J Anim Sci 29 (1):100-108.

Bhandari N, Nepali DB, Paudyal S. (2013) Assessment of bacterial load in broiler chicken meat from the retail meat shops in Chitwan, Nepal. Int $\mathbf{J}$ Infect Microbiol, 2(3): 99-104.
Elgadir MA (2017) Water activity stability of cold storage broiler chicken breast muscles fed on diets containing medicinal plants. International Journal of Scientific Engineering and Applied Science, 3(3): 226-235.

Aidani E, Aghamohammadi B, Akbarian M, Morshedi M, Hadidi M, Ghasemkhani $\mathrm{N}$, Akbarian A, (2014). Effect of chilling, freezing and thawing on meat quality: a review. International Journal of Biosciences, 5(4): 159-169.

FSSAI, 2012. Food Safety and Standard Authority of India, Ministry of Health \& Family Welfare, FDA Bhavan, Kotla Road, New Delhi-110002

IpcakHH, and Alcicek A, (2018). Addition of Capsicum oleoresin, Carvacrol, Cinnamaldehyde and their mixtures to the broiler diet II: Effects on meat quality. Journal of Animal Science and Technology, 60: 9

Cheng-Yung L, Kuo HY, Wan TC (2014) Effect of Free-range rearing on meat composition, physical properties and sensory evaluation in taiwan game hens. Asian Australas. J. Anim. Sci, 27(6): 880-885.

Boonchoo N,Tangduangdee C,Asavasanti S, (2015). Effects of ohmic heating on thawing time, energy consumption and water holding capacity (WHC) of frozen chicken breast. The 27th Annual Meeting of the Thai Society for Biotechnology and International Conference November 17-20, 2015 Mandarin Hotel Bangkok by Centre Point, Bangkok, Thailand

Oliveira MR, Gubert G, Roman SS, Kempka AP, Prestes RC. (2015) Meat Quality of Chicken Breast Subjected to Different Thawing Methods. Brazilian Journal of Poultry Science, 17(2): 165-171.

Saelin S, Wattanachant S, Youravong W. (2017).Evaluation of water holding capacity in broiler breast meat by 
electrical conductivity. International Food Research Journal 24(6): 25932598

Snedecor GW, Cochran WG (1994). Statistical methods. Eighth edition, IOWA State University Press, USA.

Soil Survey Staff. (1993). Soil survey manual. USDA, Soil Conservation Service, Agricultural Handbook No. 18, U.S. Gov. Print. Office, Washington, D.C Daszkiewicz T, Kubiak D, Panfil A. (2018). The effect of long-term frozen storage on the quality of meat (Longissimus thoracis et lumborum) from female roe deer (Capreolus capreolus 1.) Hindawi Journal of Food Quality, 1-7.

Van Laack R, C.-H. Liu, Smith MO, Loveday
HD(2000) Characteristics of pale, soft, exudative broiler breast meat, Poultry Science, 79(7): 1057-1061.

Woelfel RL, Owens CM, Hirschler EM, Martinez-Dawson R, and Sams AR(2002). The characterization and incidence of pale, soft, and exudative broiler meat in a commercial processing plant. Poultry Science, 81(4): 579-584.

Yu LH, Lee ES, Jeong JY, Paik HD, Choi JH, Kim CJ, (2005) Effects of thawing temperature on the physicochemical properties of pre-rigor frozen chicken breast and leg muscles, Meat Science, 71(2): 375-382.

\section{How to cite this article:}

Rajkumar, R., A. Irshad, and Pandiyan, C. 2020. Influence of Different Thawing Methods on Physico-chemical and Microbiological Characteristics of Broiler Chicken Meat. Int.J.Curr.Microbiol.App.Sci. 9(11): 1213-1220. doi: https://doi.org/10.20546/ijcmas.2020.911.142 